\title{
Integrating The Topic Of Audiovisual Translation Into The Curriculum For Translation Education In Indonesia
}

\author{
Niken Paramita ${ }^{1)^{*}}$, Anizar Ahmad Yasmin ${ }^{2)}$ \\ ${ }^{1)}$ English Language Teaching-Universitas Negeri Malang \\ ${ }^{2)}$ ICT Unit-Universitas Brawijaya \\ Jl. Semarang 5 Malang, 65145. E-mail: niken.paramita@gmail.com*
}

\begin{abstract}
This paper aims to find out what actually the industry needs from their translators when performing Audiovisual (AV) translation, and whether the academic environment, in this case the English Department of Universitas Brawijaya Malang, has fulfilled the industrial needs. From the results of academic document observation and questionnaire to owners of an Indonesian localization company, the authors make some recommendations to include the topic of AV translation in the course of translation that is currently available in the aforementioned English Department. The topic is comprised of the basic concepts of AV text and AV translation, practice of dubbing script translation, and practice of subtitling. The modification of the available course is expected to make the course more relevant to the current needs.
\end{abstract}

Key Words: audiovisual translation, curriculum, instructional materials, translation course, translation pedagogy

\begin{abstract}
Abstrak: Penelitian ini bertujuan untuk mengetahui kebutuhan industri penerjemahan dalam penerjemahan AV serta melihat apakah lingkungan akademiknya, dalam penelitian ini adalah Jurusan Sastra Inggris Universitas Brawijaya Malang, telah memenuhi kebutuhan industri penerjemahan. Hasil observasi dokumen akademik dan kuisioner yang diberikan kepada pemilik industri penerjemahan dan pelokalan di Indonesia, maka topik terjemahan AV dapat dimasukkan dalam mata kuliah terjemahan pada Jurusan Sastra Inggris Universitas Brawijaya Malang. Topik terjemahan AV terdiri dari konsep dasar teks AV dan terjemahan teks AV, praktik terjemahan naskah penyuaraan atau dubbing, dan praktik subtitling. Modifikasi pada mata kuliah terjemahan yang tersedia diharapkan dapat memenuhi kebutuhan industri terjemahan saat ini.
\end{abstract}

Kata kunci: terjemahan audiovisual, kurikulum, materi instruksional, mata kuliah terjemahan, pendidikan terjemahan

Current development has shown that there is a high increase in the market of audiovisual content industry from year to year (PricewaterhouseCoopers, 2012). As technological devices become closer to people's daily activities, the information, entertainment, and other content that are audiovisual in nature are getting more recognition. This is because people are getting their daily intakes of information and entertainment from their devices. Most of this information and entertainment can be defined as a part of audiovisual content, along with the wealth of audiovisual content industry that produces the content.

In Asian developing countries context, currently the market of audiovisual content is quite small com- pared to the western/developed countries market. However, the growth rate of developing countries' market of audiovisual content has become much higher (Koshpasharin \& Yasue, 2012). This shows that the demand for audiovisual content is even higher in Asian developing countries, and it is growing substantially.

Most of the content is available on languages that are foreign or secondary to the Asian market country (English/Japanese/French/Germany/others). This creates a demand for a good translation of foreign language audiovisual content into a local language. Ashcraft (2010), for instance, found that Japanese gamers preferred to play subtitled or dubbed foreign videogames. Regarding movie subtitle, (Siegel, Roxborough, 
Richford, \& Tsui, 2013) found that major film studies are investing more on dubbing foreign animated and family oriented movies into a local language, while also adjusting the content to account for local sensitivities. The other kind of audiovisual content, online content, also sees similar trend; Robertson (2009) found that subtitled online content or videos are more easily discovered and being watched longer than non-subtitled ones.

This growing demand for audiovisual translation can be seen as a need of the industry that should be accommodated by colleges from related majors to prepare their students for their future. Research and inclusion of audiovisual translation into an academic curriculum has been growing and flourishing in European context (Toda, 2008; Cintas, 2008; McLoughlin, 2009), but it has been scarce in the context of developing countries in Asia, although as stated above, the developing countries market is growing rapidly.

As such, this research is aimed to find out the need of the audiovisual translation industry in regard to translators' competence, and whether or not the academic environment fulfills the industry's need. To get further understanding on audiovisual translation, we will discuss the nature of audiovisual translation in the following section.

Audiovisual translation can be generally defined as translation of the audio-verbal element (dialogues, off-screen voices, songs) of an audiovisual text. The audiovisual text itself can manifest in various forms such as movies, advertisements, online videos and contents, applications, etc. Translation of audiovisual text has some similarity and some contrasting differences that set it apart from general, more classical translation taught in university translation courses. Cho (2014) noted the unique characteristic of audiovisual translation where it is commonly referred to as "constrained translation". This concept is related to how audiovisual translation should consider other elements. When the text is also made up of other elements such as picture and audio and constraints of time, the translation should also consider the content synchrony with other message components in both the original video and the translated one.

Furthermore, Cho (2014) noted that audiovisual translation is something that is beyond the linguistic level. Aside from translating the source text, the translator must be able to capture the feel of the other elements into the translated target text. This can be further related to the cultural aspect between the source media and the target translated product.
Another essential uniqueness of audiovisual text such as films and TV dramas as noted by Cho (2014) is its convention of prefabricated orality. This is related to how the speech in the text seems to be natural but actually is planned, or prefabricated. The texts in such audiovisual materials are written to be spoken as if it is not written. This is a unique characteristic that should be understood by the translator in order to produce a good translation that can match the source text.

In European context, among the audiovisual teaching projects of note is the one by Toda (2008), in which he conducted audiovisual teaching research on five different EU countries. The emphasis of the audiovisual in the European context is on practical skills and the standards applied in different countries, as each country already has its established standards of audiovisual preferences and regulations. The projects were conducted quite thoroughly in the practice of dubbing, voice over, and subtitling as there are many universities with specialization in the field of audiovisual content production and translation. The general process of the teaching includes initial lectures on the modes of translation, continued with watching the whole movie, and researching as homework, then in class exercise of subtitling five-minute clips.

Related to the language learning, Gambier (2006) noted that subtitled content has helped people to learn a foreign language. Related to this, the concern should be on providing good translation so that it can be used as an effective way of learning the foreign language. One way toward providing good translation is by including the elements of subtitling translation in the curriculum of related majors at the university level. Through the inclusion of good practice of subtitling and/or audiovisual translation, students can have good foundation toward their way in contributing to producing good translated content that can help others to learn a foreign language.

Aside from the language learning effect of good subtitled content for the viewers, researchers have also noted that subtitling/audiovisual translation has also helped the practitioner in developing the skills necessary for their future needs and development of oral comprehension skills (Orrego-Carmona, 2013; Talavan, 2010). Non-professional translators, or in academic settings, students, can work collaboratively in subtitling activities, and in doing so, they have the chance to develop various skills that can be useful to their future jobs, as it is a practice that is widely needed by the current indus- 
try. In doing subtitling, students also gain the opportunity to achieve better understanding of oral input, instead of only grammatical and textual rules since they are facing the language used in communicative setting. It can be said that subtitling, or audiovisual translation, provides students with an environment for the development of necessary linguistic skills as students are listening to the audiovisual material, reading comprehension through reading the source subtitle or other text, and writing skills as they write the target translation.

According to the background of research, thus the problems of this research deal with (1) the need of he industry from their translator when performing $\mathrm{AV}$ translation, (2) whether the academic environment met the industry's needs, (3) If it has not, what can be included in the current translation curriculum or course to make it more suitable to industry's needs?

\section{METHOD}

To gain further understanding of the issue and answer the research questions, the research is designed in the form of qualitative study, as qualitative study allows for investigation of phenomena in their natural settings (Ritchie, 2003). Two kinds of data are chosen for the research, generated data in the form of individual interview, and naturally occurring data in the form of current curriculum and also additional data from the previous research.

The interview questions were adapted from readily available interview materials specifically designed for AV research (Av-kääntäjät, 2017). The questions in the original template were adapted to gain better understanding on the issue of the AV industry's translation needs. The information asked in the interview was related to the company's identity, the translator recruitment process, preference, translator's competence, and the process of AV translation work.

Literature review from closely related research was conducted on one specific study by Dewi (2012) on the curriculum of translation education in Indonesia. The study is quite informative in shedding light on the current condition of translation education at the tertiary level in Indonesia.

To get a more complete picture of the current condition of translation education in Indonesia, the current research also conducts document analysis on more universities that are not included in Dewi's (2012) research (Universitas Brawijaya and Universitas Islam Negeri Sumatera Utara). The documents used for the analysis are the curriculum and/or course outline of the translation course.

\section{RESULTS AND DISCUSSION}

From the results of the interview with the owners of an Indonesian localization company, it was found that there were certain standards and expectations coming from the localization industry in Indonesia (represented by the company being interviewed) toward the translators they employ. First, the academic background becomes a part of consideration for translator recruitment. It is not the sole or dominant factor in deciding whether to hire a translator, yet still holds a significant role in the decision making process.

In this regard, the company owners preferred hiring graduates of language departments, whether it is a foreign language or bahasa Indonesia. They assumed that those graduates loved to read and therefore had better language command and linguistic knowledge, especially in bahasa Indonesia, which is required in the localization industry.

Also, they expected that the translators possessed certain competences for doing their job. First, the translators should have linguistic competence in the source language (mostly English), such as mastering English idioms and slang, as well as in the target language (standardized bahasa Indonesia). They should also have creativity in choosing the proper vocabulary and grammatical structure while translating. Next, the translators should be knowledgeable about various disciplines \& subject matters, since they are required to work on movies and/or television programs with various themes and genres. Besides, they should possess sufficient computer skills, including the ability to make use of the Internet for information-mining.

The above statement matches Janecová's (2012) notion about the competences required for future audiovisual translators. They are "professional competence (basic theoretical knowledge related to the field of audiovisual translation, orientation in audiovisual translation practice, knowledge on specifics of audiovisual translation), language competence (good knowledge of both source and target language, operation with language within translations, special language adjustments or editing), cultural competence (specific interpretation skills and cultural-communication competence), [and] technical competence (super-translation operations, e.g. segmentation of dialogues, segmentation of subtitles, spotting, etc.)." 
So far, the translators' shortcomings in translating subtitles or dubbing scripts were said to come from their lack of linguistic sensitivity and mastery, as well as their lack of information-mining efforts. Based on these experiences, the company owners confirmed that the topic of audiovisual translation needed to be introduced in academic settings. The imported videos (e.g. feature films or TV programs) that should be translated can function as authentic learning sources for the students to improve their foreign language skills. To further enhance the students' competence and potentials, especially in the case of audiovisual translation, it was suggested that the students get more practice on audiovisual translation, along with constructive peer feedback, as well as additional (in-class or out-class) activities connecting the students, the university, and the related industry in the form of guest lecture or internship.

To confirm whether the industry's needs and expectations are fulfilled by the national academic environment in Indonesia, i.e. formal institutions of higher education, a review was conducted toward a previous presentation by Dewi(2012). The presentation was based on her observation toward the translation courses available in a number of Indonesian universities (i.e. UniversitasTerbuka, STBA LIA, Universitas Nasional, Universitas Indonesia, Universitas Gunadarma, Universitas Udayana, Universitas Negeri Sebelas Maret, and Universitas Negeri Jakarta). At the end of her presentation, Dewi proposed a guideline for undergraduate and graduate translation programs' curriculum in Indonesia, stressing the importance of teaching translation theories in the courses while noting the importance of practice for the students to become fully fledged translation professionals.

Upon observation, Dewi's proposed guideline for the curriculum provided some useful explanation. However, it was not immediately applicable as it only served as a guideline consisting of a list of some important points for the consideration of curriculum development. With regard to audiovisual translation topics, it was found that there were only two universities that include audiovisual translation in their Translation courses. They were Universitas Nasional and STBA LIA.

To complement the information obtained from Dewi's presentation, the authors did observation on curriculum of Translation courses at Universitas Nasional and STBA LIA. Also, other universities' curriculums were observed to see whether there were other institutions which were not included in Dewi's study. The result was both the English Department at Univer- sitas Brawijaya and the English Language Teaching (ELT) Department at Universitas Islam Negeri Sumatera Utara incorporated the topic of Audiovisual Translation in their Translation courses. Therefore, among the total of 12 (twelve) foreign language departments (English and English Language Teaching departments/study programs) that were observed and reviewed, only four of them took into account Audiovisual Translation in the Translation courses being offered.

At the English Department of Universitas Nasional, the topic on Audiovisual Translation was covered in the courses of "Movie Translation/ Subtitling I" and "Movie Translation/ Subtitling II", where the students received such learning materials as theories and practice of movie subtitling. The same materials were given to the students of the English Department of STBA LIA taking the course of "Subtitel (Subtitling)". The English Language Teaching Department of Universitas Islam Negeri Sumatera Utara briefly touched upon Audiovisual Translation by having the in-class activity of subtitling practice in the course of "English-Indonesian Translation". Meanwhile, the English Department of Universitas Brawijaya had the analysis of film subtitles as one of the students' activities in the course of "Translation and Interpretation".

Based on these findings, it may be concluded that in Indonesian academic environment, there is still very little attention paid to Audiovisual Translation as a growing part of Translation, both as practical endeavors and as academic ventures. The observation and review were conducted on English (and ELT) departments and study programs in major Indonesian universities located in major cities in the country. As such, those departments are expected to recognize their significant role in cultivating their students' various potentials and preparing them for the future by attending to the latest global trend and development, in this case the field of audiovisual translation, as well as creating a link to the concerned industries and institutions.

This concern can be confirmed by the statement of the localization company owners about the worth of incorporating Audiovisual Translation as a part of academic curriculum in higher education institutions. They agreed that it would be a beneficial thing and that even the industry could be a part of students' learning process.

It might be safe to say, then, that English departments in most influential campuses in Indonesia are still oblivious to these facts. At the few departments that actually include audiovisual translation in their 
Translation courses, the materials and activities being provided only revolve around subtitling and subtitle analysis. It can be argued that the decision to include subtitling and subtitle analysis might have to do with the mastery of linguistic aspect of translation as well as the translation techniques and strategies. Although there is nothing wrong with this reasoning, a more up-to-date curriculum for Translation education in Indonesia is urgently needed.

With this in mind, the authors attempt to propose learning materials and activities for higher education students having Translation courses in their study, by paying attention to the abovementioned list of translators' competences suggested by Janecová (2012). The proposed materials and activities mainly consist of theoretical concepts of audiovisual translation and practice of audiovisual translation.

Adopting the Course Specifications for "Screen Translation English - Spanish" at Ghent University, Belgium(2016), the material on the theory of audiovisual translation can cover the discussion on the concept of multimodal text and the elements of an audiovisual text, the history of audiovisual translation, and the strategies and techniques of audiovisual translation. It is hoped that by knowing the theory of audiovisual translation, the students can understand the nature of audiovisual text and audiovisual translation, which will be useful when being applied to the translation practice.

Then, as suggested by Cho (2014), the practice of audiovisual translation can be conducted in three stages. The first stage is analyzing Indonesian subtitles and Indonesian dubbing done to English-language films or TV programs. By analyzing the already available translation, the students can critically assess the work of professional translators and perform error analysis. Cho (pp.66) stated that it can also help students build their confidence in performing audiovisual translation.

The second stage is the actual translation practice, where the students can translate subtitles and/or dubbing script using multimodal transcription (Thibault and Baldry, 2000; inTaylor, 2009). The multimodal transcription itself is a five-column table breaking down the scenes of an audiovisual text to help subtitlers-intraining. The first column shows time in seconds, the second illustrates each frame of the film, the third gives detailed description about the scene and the setting, the fourth contains the dialogs and music in the frame, and the last comprises the translation of the dialogs. This practice is still done manually, i.e. without any particular software, to make the students get used to applying the principles and techniques of translating subtitles and dubbing scripts without worrying about the technical nitpicks of using software.

The third stage of translation practice is subtitling with the help of subtitle editing software. Cho stated that this practice is in line with the latest technology development and is capable of encouraging students' participation. The proposed activities may include lectures (especially for teaching the theory of audiovisual translation), small-group work, and individual translation projects. Also, as mentioned previously, a guest lecture session from the localization industry, whether by a working translator or an owner of a localization company, can be a supplementary activity. The assessment can be conducted through students' presentation and portfolio.

\section{CONCLUSSION}

The inclusion of Audiovisual Translation into the existing Translation courses in Indonesian universities and colleges is very beneficial and important - for the students, the university and the industry alike. It can expose the students to the latest development and authentic materials in translation and localization industry. Simultaneously, the students can further train their translation skills, increase their linguistic competence, and build their technological and professional competence. In addition, the existing courses or materials on Audiovisual Translation in some of Indonesian Universities should be further improved so that they reflect the actual industry's needs.

\section{REFERENCES}

Ashcraft, B. (2010, November 4). The surprising ways Japanese games are changed for Westerners. Retrieved from Kotaku: https://www.kotaku.com.au/2010/11/ the-surprising-ways-japanese-games-are-changedfor-americans/

Av-kääntäjät. (2017). Questionnaire letter to the translation companies. Retrieved from Av-kääntäjät: http:/ /www.av-kaantajat.fi/in_english/introducing trans lation companie/questionnaire letter to the tran/

Cho, S. (2014). Basic concept in the theory of audiovisual translation. Retrieved from Hankuk University of Foreign Studies: http://builder.hufs.ac.kr/user/ibas/ No31/15.pdf.

Cintas, J. (2008). The didactics of audiovisual translation. Amsterdam: John Benjamins. 
Dewi, H. (2012, November 12). A proposed curriculum for translation education in Indonesia (Powerpoint slide). Presented in Seminar Nasional Industri Bahasa. Malang: UPT Bahasa Politeknik Negeri Malang.

Díaz-Cintas, J. (2008). Introduction: The didactics of audiovisual translation. In J. Díaz-Cintas, The didactics of audiovisual translation (pp. 1-18). Amsterdam/ Philadelphia: John Benjamins.

Gambier, Y. (2006). Multimodality and audiovisual translation. MuTra 2006 - Audiovisual translation scenarios: conference proceedings. Copenhagen: $\mathrm{Mu}-$ Tra.

Ghent University. (2016). Screen translation EnglishSpanish course specifications. Retrieved from Ghent University Web Site: https://studiegids.ugent.be/ 2016/EN/studiefiches/A703125.pdf.

Janecová, E. (2012). Teaching audiovisual translation: theory and practice in the twenty-first century. Çankaya University journal of humanities and social sciences 9/1, pp.17-29.

Koshpasharin, S., \& Yasue, K. (2012). ERIA. Retrieved from ERIA: http://www.eria.org/RPR-FY2012-13.pdf

McLoughlin, L. (2009). Subtitles in translators' training: a model of analysis. Romance studies, 174-185.

Orrego-Carmona, D. (2013). Using non-professional subtitling platforms for translator training. Rivista internazionale di tecnica della traduzione = International journal of translation n.15, 129-144.
PricewaterhouseCoopers. (2012). PwC annual reports 2012. Retrieved from PricewaterhouseCoopers web site: https://www.pwc.co.uk/assets/pdf/annual-report-2012.pdf.

Ritchie, J. (2003). The application of qualitative methods to social research. In J. Ritchie, \& J. Lewis, Qualitative research practice: a guide for social science students and researchers. London: Sage.

Robertson, M. (2009, March 30). Subtitles increase video viewing by $40 \%$ - research. Retrieved from tubular insights: http://tubularinsights.com/subtitlesviewing/.

Siegel, T., Roxborough, S., Richford, R., \& Tsui, C. (2013, March 14). Inside the weird world of international dubbing. Retrieved from Hollywood Reporter: http:/ /www.hollywoodreporter.com/news/argo-djangounchained-inside-weird-427453.

Talavan, N. (2010). Subtitling as task and subtitles as support: pedagogical applications. In J. Cintas, A. Matamala, \& J. Neves, New insights into audiovisual translation and media accessibility. Amsterdam, New York: Rodopi.

Taylor, C. (2009). Pedagogical tools for the training of subtitlers. In J. a. Díaz-Cintas, Audiovisual translation: language transfer on screen (pp. 214-228). Hampshire and New York: Palgrave Macmillan.

Toda, F. (2008). Teaching audiovisual translation in a European context: An inter-university project. In J. Cintas, The didactics of audiovisual translation. Amsterdam: John Benjamins. 